УДК 159.922 .82$.

DOI https://doi.org/10.26661/2310-4368/2020-2-18

\title{
СТАТЕВІ ОСОБЛИВОСТІ РОЗВИТКУ ЕМОЦІЙНОГО ІНТЕЛЕКТУ ТА ЙОГО ЧИННИКІВ У ЮНАЦЬКОМУ ВІЦІ
}

\author{
Журавльова Л. П. \\ доктор психологічних наук, професор, \\ завідувач кафедри психологї \\ Поліський національний університет \\ вул. Старий бульвар, 7, Житомир, Україна \\ orcid.org/0000-0003-4020-7279 \\ lpz2008@ukr.net \\ Лaаc М. В. \\ аспірантка кафедри сочіальної та практичної психологї \\ Житомирський державний університет імені Івана Франка \\ вул. Велика Бердичівська, 40, Житомир, Україна \\ orcid.org/0000-0002-8473-4188 \\ maryna.petruchenko@gmail.com
}

\begin{abstract}
Ключові слова:
емоиійний інтелект, внутрішньоособистісний та міжособистісний емоиійний інтелект, емпатія, рефлексія, емоиійна саморегуляиія, особистісна зрілість.
\end{abstract}

Статтю присвячено обгрунтуванню поняття емоційного інтелекту, визначенню його внутрішніх чинників та дослідженню особливостей розвитку феномена в юнацькому віці. Метою статті $€$ дослідження статевих особливостей розвитку емоційного інтелекту та його чинників у юнацькому віці. Вибірку досліджуваних склали 25 хлопців та 25 дівчат віком від 15 до 17 років. Використано такі методики: опитувальник «ЕмІн» Д.В. Люсина, тест на визначення інтегральної емпатії у підлітків та юнаків Л.П. Журавльової, методика діагностики емоційної зрілості особистості (МДЕЗО) О.С. Кочаряна, М.А. Півня.

Результати вказують на те, що не виявлено статевих відмінностей між показниками загального емоційного інтелекту, проте знайдено достовірні відмінності між внутрішньоособистісним та міжособистісним емоційним інтелектом. Знайдено статистично значущі відмінності між особливостями функціонування чинників розвитку емоційного інтелекту. У юнок домінує міжособистісний інтелект, дуже високий рівень емпатії, сприяння не на шкоду собі, емоційна експресивність, рефлексія. У юнаків домінує внутрішньоособистісний емоційний інтелект, низький рівень інтегральної емпатії, альтруїстична форма емпатії, прийняття власних емоцій, контроль експресії. У юнацькому віці дівчата більш схильні до сприяння не на шкоду собі, а хлопці - до альтруїстичної поведінки. У більшості дівчат виражена емоційна експресивність, хлопці краще приймають власні емоції. Юнаки та юнки ідентифікують власні емоції, усвідомлюють, розуміють причини їх виникнення, можуть їх вербалізувати, раціонально ставляться до минулого емоційного досвіду, розставляють пріоритети у своєму житті. Визначено специфіку впливу чинників на розвиток емоційного інтелекту у юнаків та юнок. Система чинників у дівчат є більш широкою та амбівалентною порівняно з хлопцями. Домінуючими внутрішніми чинниками емоційного інтелекту у дівчат $є$ як нижчі форми емпатії (індиферентність), так і вищі (сприяння не на шкоду собі, альтруїстична емпатія). Антиемпатія $\epsilon$ амбівалентним чинником емоційного інтелекту. У юнаків домінуючим внутрішнім чинником емоційного інтелекту є прийняття власних емоцій. 


\title{
GENDER FEATURES OF DEVELOPMENT OF EMOTIONAL INTELLIGENCE AND ITS FACTORS IN YOUTH AGE
}

\author{
Zhuravleva L. P. \\ Doctor of Psychological Sciences, Professor, \\ Head of the Department of Psychology \\ Polissya National University \\ Staryi bulvar str., 7, Zhytomyr, Ukraine \\ orcid.org/0000-0003-4020-7279 \\ lpz2008@ukr.net
}

Laas M. V.

Graduate Student at the Department of Social and Practical Psychology

Zhytomyr Ivan Franko State University

Velyka Berdychivska str., 40, Zhytomyr, Ukraina

orcid.org/0000-0002-8473-4188

maryna.petruchenko@gmail.com

Key words: emotional intelligence, intra-personal and interpersonal emotional intelligence, empathy and its forms of manifestation, components of emotional intelligence, reflection, emotional self-regulation, personal maturity.
The article is devoted to the substantiation of the concept of emotional intelligence, determination of its internal factors and research of the peculiarities of the phenomenon development in young people. The aim of the article is to investigate the sexual features of the development of emotional intelligence and its factors in young people. The sample was 25 boys and 25 girls, aged 15 to 17 years. Methods used: Emin questionnaire D.V. Lusin, test for determination of integral empathy in young people and young age L.P. Zhuravleva, method of diagnostics of emotional maturity of the person (MDESO) A.S. Kocharyan, M.A. Piven.

The results indicate that no gender differences were found between the indicators of general emotional intelligence, but significant differences were found between intrapersonal and interpersonal emotional intelligence. Statistically significant differences were found between the features of the functioning of the factors of emotional intelligence development. The girls are dominated by interpersonal intelligence, a very high level of empathy, promotion not to the detriment of oneself, emotional expressiveness, and reflection. The boys are dominated by intrapersonal emotional intelligence, low levels of integral empathy, altruistic form of empathy, acceptance of their own emotions, and control of expression. Young men and women identify their own emotions, realize, understand the reasons for their occurrence, can verbalize them, rationally relate to past emotional experiences, and set priorities in their lives. At a young age, girls are more inclined to promote not to the detriment of themselves, and boys - to altruistic behavior. Most girls have expressed emotional expression, boys are better at accepting their own emotions. The specific influence of factors on the development of emotional intelligence in boys and girls is determined. The system of factors in girls is broader and more ambivalent than boys. The dominant internal factors of girls' emotional intelligence are both lower forms of empathy (indifference) and higher (real assistance, altruistic empathy). Antiempathy is an ambivalent factor in emotional intelligence. In boys, the dominant internal factor in emotional intelligence is the acceptance of one's own emotions. 
Постановка проблеми. Емоційний інтелект є однією з головних складових частин у досягненні успіху. Для юнацького віку є важливим його розвиток, адже він допомагає активно включатися в різні події життя, правильно будувати стосунки 3 оточенням, самореалізовувати себе як у професійному (взаємодія 3 керівництвом та колегами), так і в особистісному (взаємодія 3 партнером та дітьми) напрямах, приймати правильні рішення для досягнення успіху.

Емоційний інтелект розглядався через поняття «розумність» $[10$, с. 76$]$. Трактували емоційний інтелект як складне психічне утворення, що має когнітивну, емоційну та особистісну природу, а одним 3 основних механізмів його розвитку $є$ емпатія [7]. Також визначали емоційний інтелект як здатність розуміти стосунки між людьми, що проявляються в емоціях, управляти цими емоціями на основі інтелектуального аналізу й синтезу [3, с. 25]. Емоційний інтелект - це «здатність до розуміння власних і чужих емоцій і управління ними», завдяки якій людина ідентифікує емоції, контролює їх, розуміє, що спричинило їх виникнення і як чинити в такому випадку [9, с. 12]. Трактували емоційний інтелект як групу ментальних здібностей, які сприяють усвідомленню й розумінню власних емоцій і емоцій оточуючих [13, с. 31]. Емоційний інтелект розглядався як здатність людини тлумачити власні емоції та емоції оточуючих, щоб використовувати отриману інформацію для реалізації власних цілей $[4$, с. 51].

Емоційний інтелект досліджувався як складне утворення, тому виокремлюють дві його форми, а саме міжособистісний і внутрішньоособистісний. Під міжособистісним емоційним інтелектом розуміється здатність людини розуміти інших, усвідомлювати мотиви їхньої поведінки та ставлення до роботи, вибирати шляхи ефективної співпраці 3 оточуючими [2, с. 23]. Під внутрішньоособистісним емоційним інтелектом розуміється властивість людини, спрямована на себе, здатність формувати точну, адекватну модель власного «Я» та використовувати іiі для ефективної життєдіяльності [2, с. 23].

Також виділяють чотири складові частини емоційного інтелекту, такі як точність оцінки й вираження емоцій, використання емоцій у розумовій діяльності, розуміння емоцій, управління емоціями $[13$, с. 31$]$; п'ять складових частин, такі як знання власних емоцій, їх самоусвідомлення, управління емоціями, самомотивація, емпатія, підтримання взаємовідносин [4, с. 52].

На розвиток емоційного інтелекту впливають біологічні та соціальні чинники [12], але недостатнім є вивчення внутрішніх чинників емоційного інтелекту.
Мета дослідження полягає у вивченні статевих особливостей розвитку емоційного інтелекту та його чинників у юнацькому віці. Завданнями дослідження $є$ здійснення теоретичного аналізу внутрішніх чинників розвитку емоційного інтелекту в юнацькому віці; дослідження статевих особливостей функціонування емоційного інтелекту та чинників його розвитку; визначення специфіки впливу чинників на розвиток емоційного інтелекту в юнаків та юнок. Для виконання цих завдань використовувалися такі методики: опитувальник «ЕмІн» [8], тест на визначення інтегральної емпатії у підлітків та юнаків [5, с. 154-161], методика діагностики емоційної зрілості особистості (МДЕЗО) О.С. Кочаряна, М.А. Півня [11].

Опитувальник «ЕмІн» використовується для діагностування інтегрального показника рівня сформованості емоційного інтелекту особистості та його структурних складових частин. Він містить такі шкали: міжособистісний емоційний інтелект, внутрішньоособистісний емоційний інтелект, розуміння емоцій, управління емоціями, загальний емоційний інтелект. Також шкала міжособистісного емоційного інтелекту вміщає такі субшкали, як розуміння чужих емоцій, управління чужими емоціями, а шкала внутрішньоособистісного емоційного інтелекту - розуміння власних емоцій, управління власними емоціями, контроль експресії.

Тест на визначення інтегральної емпатії у підлітків та юнаків використовувався для з'ясування інтегрального показника емпатії та рівня iii розвитку, форм прояву (антиемпатія, індиферентність, співпереживання, співчуття, внутрішне сприяння, реальне сприяння не на шкоду собі та реальне сприяння на шкоду собі або альтруїстична емпатія).

Методика діагностики емоційної зрілості особистості (МДЕЗО) застосовувалася для з'ясування особливостей емоційної сфери та емоційної саморегуляції. Відповідно до предмета дослідження використовувалися такі шкали: рефлексія емоцій; емоційна саморегуляція; емоційна експресивність; прийняття власних емоцій.

Дослідження проводилося на базі Житомирської загальноосвітньої школи № 14. Загальна вибірка складала 50 осіб, зокрема 25 дівчат та 25 хлопців раннього юнацького віку (15-17 років).

Виклад основного матеріалу дослідження. Розвиток емоційного інтелекту в період юності можна назвати «серцевиною його розвитку» $[1$, c. 22]. Він залежить від віку, адже показники збільшуються між раннім підлітковим віком (11-13 років) та ранньою дорослістю (20-40 років), тобто в юнацькому віці можемо спостерігати його інтенсивний розвиток. В 16-17 років також до найвищих форм прояву може розвинутись інте- 
гральна емпатія, в основі якої лежить психічна соціально-духовна природа людини. На духовному рівні емпатійність проявляється у трансфінітній емпатії, а саме надчуттєвому проникненні в життєвий світ іншої людини, духовній єдності 3 Іншим [5]. Підвищується емоційна саморегуляція юнаків та дівчат, проте зменшується роль міжособистісної комунікації, поступаючись здібностям, що пов'язані з організацією внутрішньої діяльності особистості. Також у цей період активно розвивається міжособистісна взаємодія, в тому числі 3 романтичним партнером [6].

Розвиток емоційного інтелекту саме в юнацькому віці зумовлюється біологічними, соціальними та внутрішніми чинниками його розвитку. Детальніше зупинимось на внутрішніх чинниках емоційного інтелекту. Проаналізувавши різні означення феномена, його структури та особливості в юнацькому віці, до внутрішніх чинників емоційного інтелекту ми віднесли емпатію, емоційну саморегуляцію, рефлексію.

Беручи до уваги ці чинники, ми провели дослідження статевих особливостей емоційного інтелекту та його детермінації впродовж юнацького віку. Дослідження мало такі етапи.

1) Вивчення особливостей міжособистісного та внутрішньоособистісного емоційного інтелекту хлопців та дівчат, а також загального рівня розвитку емоційного інтелекту.

2) Дослідження чинників розвитку емоційного інтелекту юнаків та юнок:

- особливості розвитку інтегральної емпатії та форми іiі прояву;

- діагностика рефлексії та емоційної саморегуляції.

3) Пошук взаємозв'язків між внутрішніми чинниками емоційного інтелекту та його компонентами.

Перший етап дослідження було присвячено вивченню емоційного інтелекту й таких його типів, як міжособистісний і внутрішньоособистісний. Результатом емпіричного дослідження було виявлення специфіки його розвитку у юнацькому віці, зокрема його статевих особливостей (рис. 1).

Не виявлено статевих відмінностей між показниками загального емоційного інтелекту юнаків та юнок, проте знайдено достовірні відмінності між їх міжособистісним емоційним інтелектом та внутрішньоособистісним, а також між їх складовими частинами (рис. 1).

Дослідження міжособистісного інтелекту й таких його складових частин, як розуміння чужих емоцій та управління чужими емоціями, показало, що дівчата мають достовірну перевагу в розумінні чужих емоцій порівняно 3 хлопцями $(\mathrm{t}=2,82$; $\mathrm{p} \leq 0,007)$. Виявлено незначущі відмінності щодо статевих відмінностей між загальними показ- никами міжособистісного емоційного інтелекту $(\mathrm{t}=1,36 ; \mathrm{p} \leq 0,2)$. Проте не знайдено достовірних статевих відмінностей між дівчатами та хлопцями в уміннях управляти чужими емоціями.

Наступним кроком нашого дослідження $\epsilon$ вивчення статевих особливостей внутрішньоособистісного емоційного інтелекту та його складових частин (розуміння власних емоцій, управління власними емоціями та контроль експресії) в ранньому юнацькому віці (рис. 1).

Хлопці виявили вищі показники внутрішньоособистісного емоційного інтелекту порівняно 3 дівчатами $(\mathrm{t}=1,71 ; \mathrm{p} \leq 0,1)$. Ці результати підтверджуються знайденими статевими відмінностями між показниками контролю експресії: хлопці мають достовірну перевагу порівняно 3 дівчатами $(\mathrm{t}=2,85 ; \mathrm{p} \leq 0,006)$.

У хлопців та дівчат юнацького віку не виявлено статевих відмінностей між показниками управління власними емоціями та розуміння власних емоцій: вони однаковою мірою здатні до емоційної регуляції, що допомагає їм адекватно реагувати в різних ситуаціях.

Доповнюють систему чинників внутрішньоособистісного емоційного інтелекту такі компоненти особистісної зрілості, як емоційна експресивність та прийняття власних емоцій. Знайдено статеві відмінності у проявах емоційної експресивності. У дівчат $\epsilon$ перевага порівняно 3 хлопцями $(\mathrm{t}=1,84 ; \mathrm{p} \leq 0,07)$.

Виявлено незначущі статеві відмінності між показниками прийняття власних емоцій $(\mathrm{t}=1,35$; $\mathrm{p} \leq 0,2)$. Хлопці порівняно 3 дівчатами 3 легкістю приймають свої позитивні та негативні емоції, завдяки чому краще йдуть на контакт з іншими.

Отже, дівчата глибше розуміють емоції інших, визначають їх емоційний стан за зовнішніми проявами емоцій. Завдяки цьому юнки краще будують конструктивне спілкування, проявляють чуйність, емоційність, співчуття до інших порівняно з хлопцями, які гірше розуміють емоції інших. Дівчата успішно розуміють та контролюють емоції інших. Завдяки цьому вони відкриті, емпатійні, краще йдуть на контакт та взаємодіють з іншими. Юнки більш емоційні у зовнішніх проявах, краще передають свій настрій оточуючим, мають активну жестикуляцію, виражену інтонацію та менше стримують себе, а хлопці характеризуються вмінням контролювати зовнішні прояви власних емоцій, стриманістю у їх прояві емоцій. Юнаки, які здатні добре керувати почуттями, готові приймати інших людей такими, якими вони є, з їхніми «плюсами й мінусами».

Загалом юнаки та меншою мірою дівчата схильні до розуміння власних емоцій, причин їх виникнення, ідентифікації, а також здатні до їх репрезентації. Це свідчить про здатність сучас- 


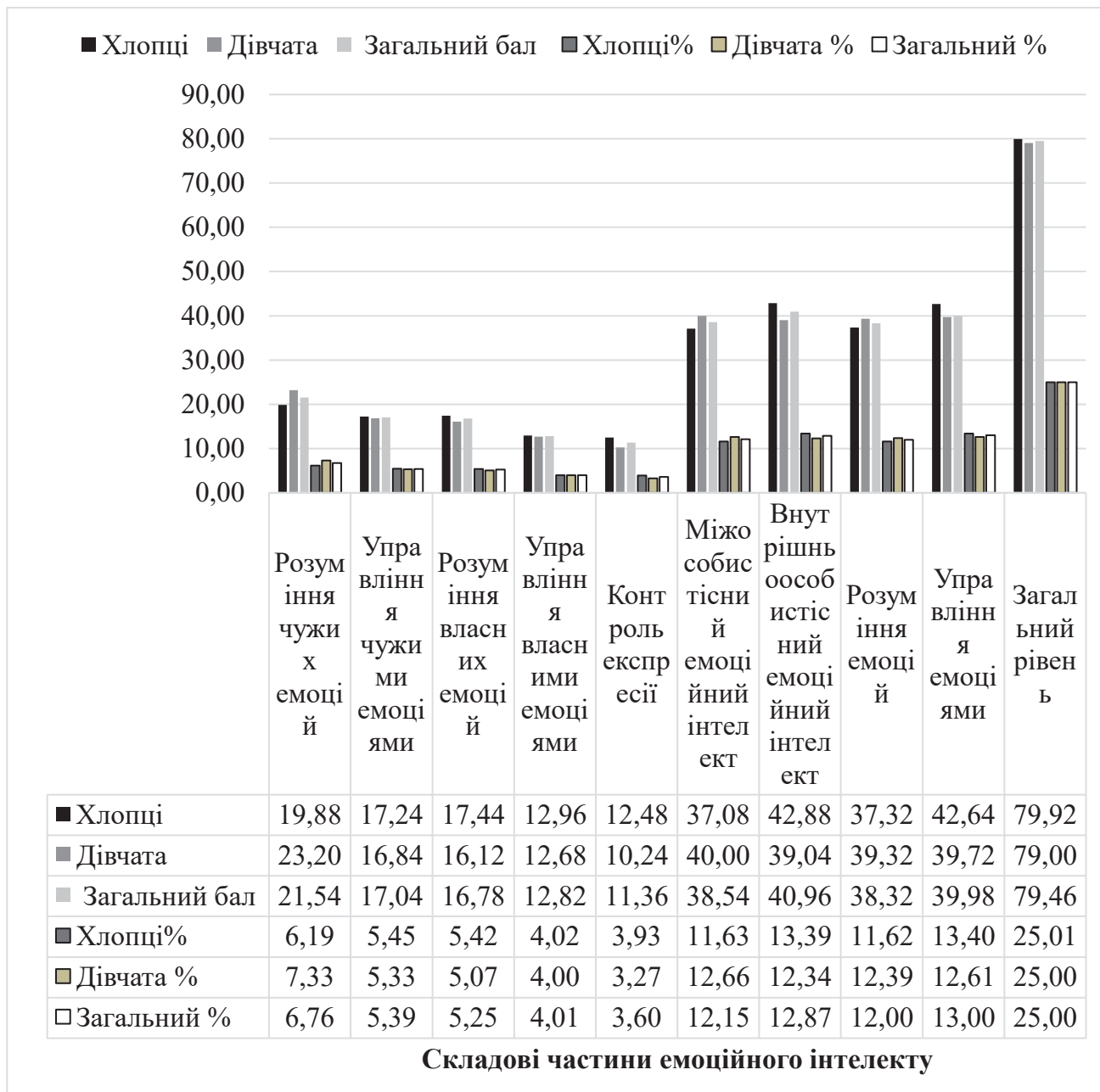

Рис. 1. Статеві особливості розвитку емоційного інтелекту в юнацькому віці

них старшокласників замислюватися над власним емоційним станом, аналізувати власні емоції та особливості їх появи, тобто активно задіювати рефлексію.

Другий етап присвячено дослідженню чинників розвитку емоційного інтелекту, зокрема інтегральної емпатії в юнацькому віці, іiі статевим відмінностям (рис. 2). Виявлено, що більшість юнаків та юнок проявляють середній рівень розвитку емпатії, а лише частка з них проявляє крайні рівні іï розвитку (низький та дуже високий рівні).

Існують достовірні відмінності у кількості хлопців та дівчат, які мають дуже високий рівень емпатії $(\mathrm{t}=1,60 ; \mathrm{p} \leq 0,1)$, а також високий $(\mathrm{t}=1,60$; $\mathrm{p} \leq 0,1)$ і низький $(\mathrm{t}=3,12 ; \mathrm{p} \leq 0,003)$. Зокрема, дівчата достовірно частіше порівняно 3 хлопцями проявляють дуже високий та високий рівні емпатіï. Вони емоційно чутливі, уважні, легко знаходять спільну мову 3 іншими, здатні зрозуміти думки й почуття більшості людей, здатні до прояву сприяння іншим не на шкоду собі.

Хлопці частіше проявляють низький рівень емпатії порівняно 3 дівчатами. Очевидно, вони відчувають труднощі під час контакту з оточуючими. Їм важко співпереживати, відгукуватися на почуття інших людей і розуміти вчинки, що скоєні в душевному пориві, вони здаються байдужими, частіше відстороненими, у них можна спостерігати підвищену агресивність, тривожність, вони схильні до точних висловлювань та раціональних рішень.

Серед форм прояву емпатії виявлено достовірні відмінності у дівчат і хлопців між показниками реального сприяння не на шкоду собі $(\mathrm{t}=2,03 ; \mathrm{p} \leq 0,05)$, альтруїстичної форми емпатії $(\mathrm{t}=2,32 ; \mathrm{p} \leq 0,02)$, внутрішнього сприяння $(\mathrm{t}=1,64$; $\mathrm{p} \leq 0,1)$ та співчуття $(\mathrm{t}=1,67 ; \mathrm{p} \leq 0,1)$ (рис. 3 ).

У юнацькому віці кількість дівчат, що проявляє реальне сприяння не на шкоду собі, достовірно більша порівняно 3 хлопцями. Вони краще емпатують іншим, прагнуть надати їм допомогу й роблять це за умови, що це не нашкодить їхнім інтересам та потребам. Це може свідчити про наявність прагматизму, потреби у власному благополуччі, вміння виокремлювати важливе та менш важливе, розпоряджатися власним життям. 


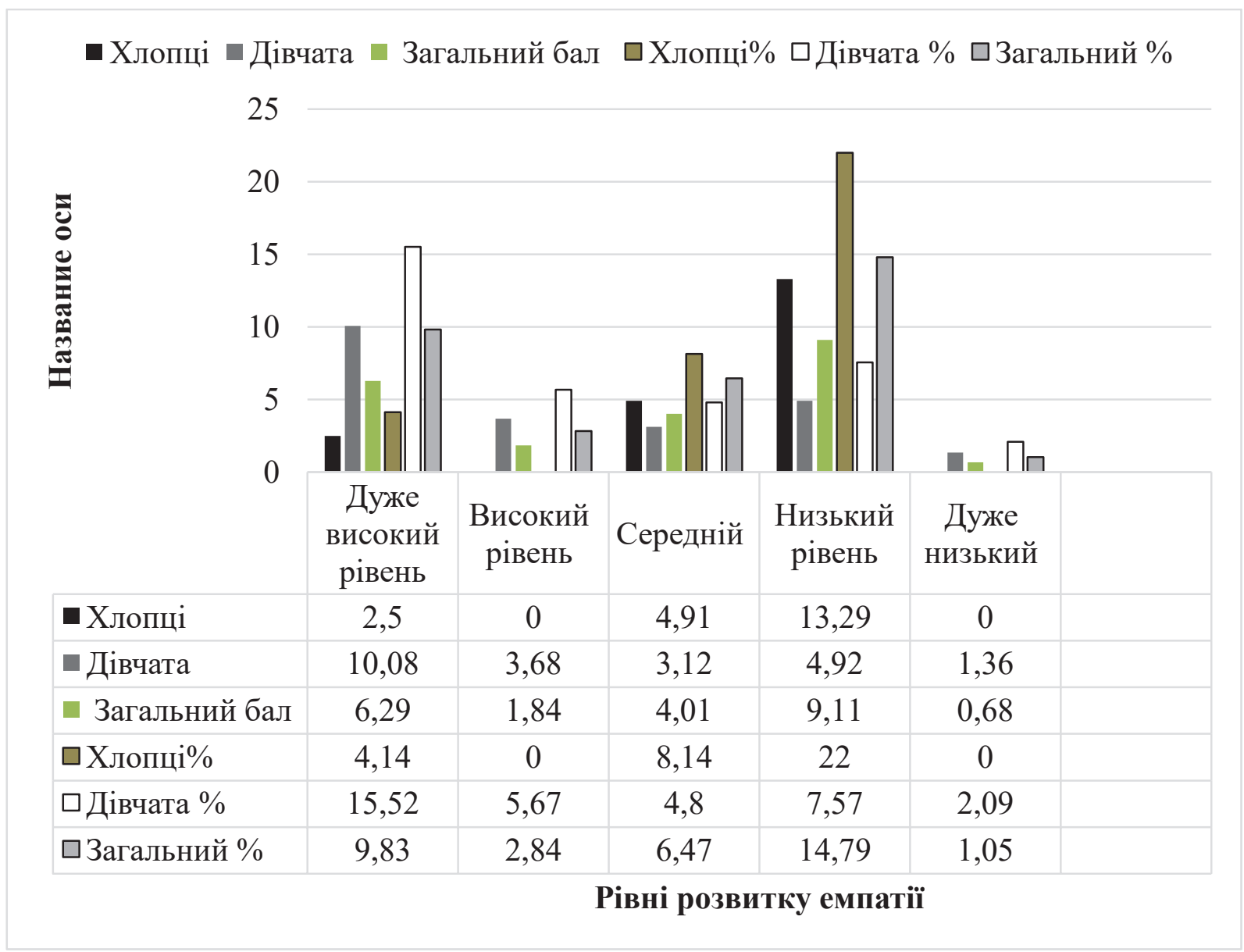

Рис. 2. Статеві особливості розвитку інтегральної емпатії в юнацькому віці

Саме така форма емпатії є іiї здоровим проявом, оптимальна для розвитку особистості. Внутрішне сприяння в дівчат також виражене краще, ніж у хлопців. Частина $з$ них прагне допомогти іншим, планує свою поведінку, але не схильна до дії. Дівчата більш співчутливі, краще сприймають негаразди іншого безвідносно до власного стану й почуттів, ніж хлопці.

У хлопців досить високо проявляється реальне сприяння на шкоду собі або альтруїстична форма емпатії, тобто вони спрямовані на іншу людину, миттєво відчувають iї стан, реалізують можливість їй допомогти навіть на шкоду власним потребам та інтересам [6, с. 61].

Юнаки часто діють імпульсивно, не замислюючись над наслідками, іноді це допомагає їм відчути себе потрібним, героєм, самоствердитися, бути впевненим у собі.

Співпереживання як переживання індивідом тих самих емоційних станів, почуттів, які відчуває інший, індиферентність як байдуже ставлення у сприйманні якоїсь ситуації, антиемпатія як почуття неприхильності, неприязні, відрази не мають статевих відмінностей на статистично значущому рівні.
На наступному етапі досліджено такі чинники розвитку емоційного інтелекту, як рефлексія емоцій та емоційна саморегуляція.

Знайдено статеві відмінності між показниками емоційної саморегуляції $(\mathrm{t}=1,58 ; \mathrm{p} \leq 0,1)$. Вона має достовірну перевагу у дівчат порівняно 3 хлопцями. Вони краще управляють власними емоціями відповідно до ситуації, ніж юнаки. Завдяки цьому вони здатні справлятися зі власними деструктивними емоціями, переживати емоції різного діапазону, глибини та інтенсивності, викликати й підтримувати бажані емоції та тримати під контролем небажані, володіють прийомами стабілізації та тонізації свого емоційного стану.

У хлопців та дівчат юнацького віку не виявлено достовірних відмінностей у показниках рефлексії емоцій. Юнаки та юнки ідентифікують власні емоції, усвідомлюють, розуміють причини їх виникнення, можуть їх вербалізувати, раціонально ставляться до минулого емоційного досвіду та прогнозують ситуацію якнайкраще, розставляють пріоритети у своєму житті.

На третьому етапі дослідження визначилась специфіка впливу чинників емоційного інтелекту на його розвиток (табл. 1). 


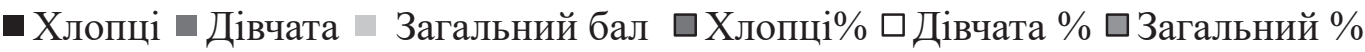

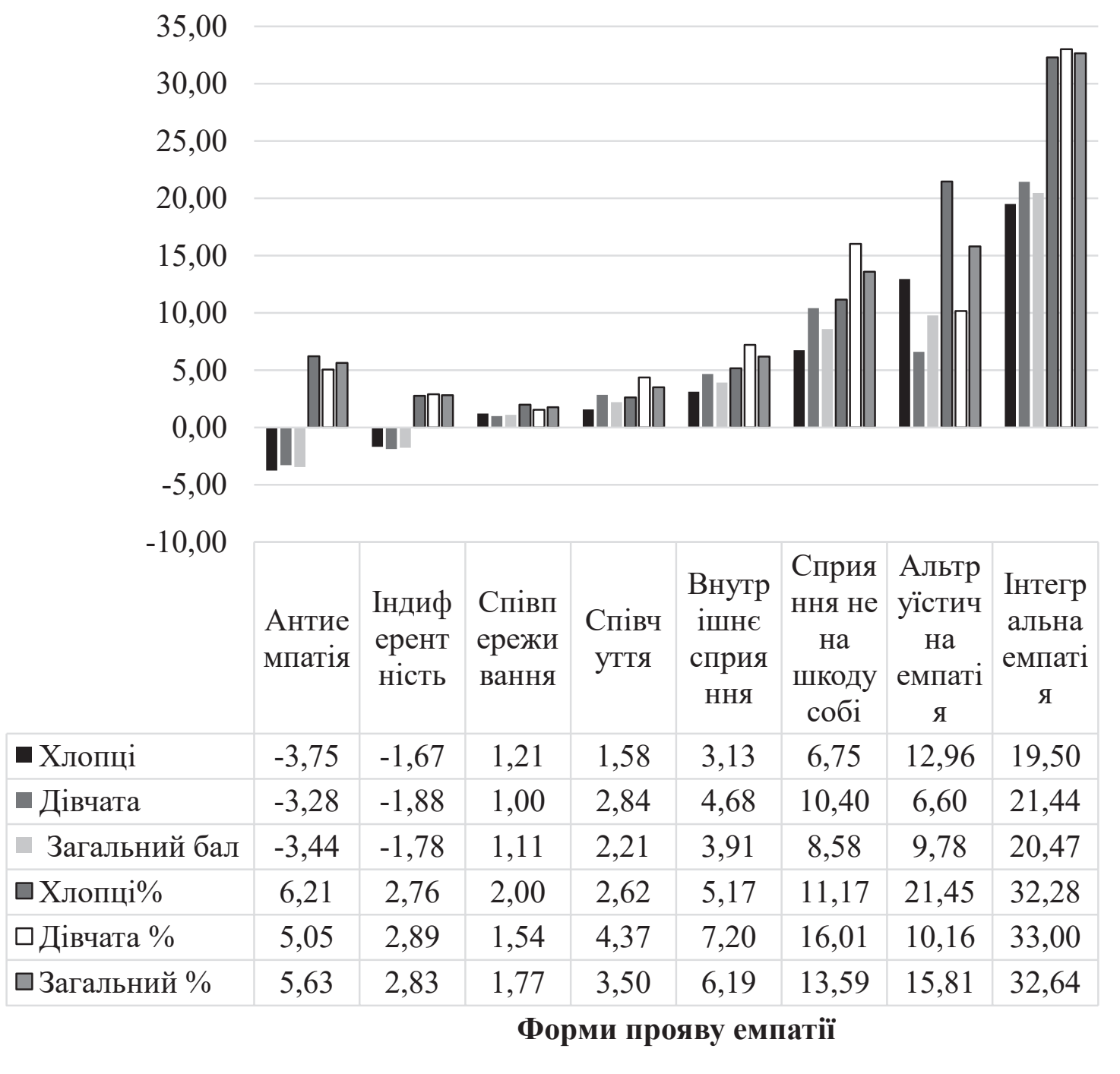

Рис. 3. Статеві особливості між формами прояву емпатії в юнацькому віці

У хлопців знайдено достовірні негативні взаємозв'язки між загальним рівнем емоційного інтелекту та показниками співчуття ( $\mathrm{p} \leq 0,05)$, емоційної саморегуляції $(\mathrm{p} \leq 0,05)$, а у дівчат - позитивні взаємозв'язки з показниками інтегральної емпатії ( $\mathrm{p} \leq 0,05)$, антиемпатії ( $\mathrm{p} \leq 0,01)$, сприяння не на шкоду собі $(\mathrm{p} \leq 0,05)$, а негативні - 3 показником шкали прийняття власних емоцій $(\mathrm{p} \leq 0,1)$.

Досліджуючи взаємозв'язки емоційного інтелекту та його складових частин (розуміння чужих та власних емоцій, управління чужими та власними емоціями) з їх чинниками, ми виявили статеву диференціацію. Чим більше прояв індиферентності в емпатогенних ситуаціях у хлопців, тим краще вони управляють чужими емоціями $(\mathrm{p} \leq 0,1)$. Їх нейтральність (байдужість) допомагає адекватно сприймати іншого й таким чином управляти його емоціями. Співпереживання та співчуття $(\mathrm{p} \leq 0,05)$ заважають управляти як власними, так і чужими емоціями, що знижує загальний рівень емоційного інтелекту. Також коли юнаки більшою мірою приймають власні емоції $(\mathrm{p} \leq 0,05)$ і менше їх регулюють $(\mathrm{p} \leq 0,05)$, то це дає їм змогу проявляти природну поведінку, що сприяє високому рівню емоційного інтелекту.

Дівчата, які проявляють дисонансну емпатію, часто не розуміють власних емоцій, що заважає адекватно управляти ними ( $\mathrm{p} \leq 0,05)$. Загалом юнки демонструють високий рівень розуміння емоцій інших, який використовують для управління ними (маніпуляція). Співпереживання в емпатогенній ситуації заважає юнкам зосередитися на переживаннях іншого $(\mathrm{p} \leq 0,1)$, вони зациклюються на власних емоціях, у них виникають егоцентричні переживання, що призводять до проявів низького рівня міжособистісного емоцій- 


\begin{tabular}{|c|c|c|c|c|c|c|c|c|c|c|}
\hline \multirow[t]{2}{*}{ Чинники ЕI } & \multicolumn{10}{|c|}{ Емоційний інтелект та його складові частини } \\
\hline & MEI & УЧЕ & PपE & BEI & УВE & PBE & $\mathbf{K E}$ & $\mathbf{P E}$ & $\mathbf{Y E}$ & $3 p$ \\
\hline \multicolumn{11}{|c|}{ Хлопці } \\
\hline Індиферентність & & $37^{3}$ & & & & & & & & \\
\hline Співпереживання & & $-40^{1}$ & & & $-40^{1}$ & & & & $-46^{1}$ & \\
\hline Співчуття & & & & $-41^{1}$ & & & $-38^{1}$ & & $-42^{1}$ & $-40^{1}$ \\
\hline Сприяння не на шкоду собі & & & & & & & & $-33^{1}$ & & \\
\hline Емоційна саморегуляція & $-46^{1}$ & $-45^{1}$ & & $-33^{3}$ & & & & & $-47^{1}$ & $-47^{1}$ \\
\hline Прийняття власних емоцій & & & $42^{1}$ & & & & & $37^{3}$ & & \\
\hline \multicolumn{11}{|c|}{ Дівчата } \\
\hline Інтегральна емпатія & & & & & & & $40^{1}$ & & $40^{1}$ & $44^{1}$ \\
\hline Антиемпатія & $49^{2}$ & $-38^{1}$ & $-45^{1}$ & $43^{1}$ & & $37^{3}$ & & $46^{1}$ & $46^{1}$ & $50^{2}$ \\
\hline Індиферентність & & & & $38^{1}$ & $36^{3}$ & & $43^{1}$ & & $33^{3}$ & \\
\hline Співпереживання & $-34^{3}$ & $-35^{3}$ & & & & & & & & \\
\hline Внутрішнє сприяння & & & & & & $41^{1}$ & & & & \\
\hline Сприяння не на шкоду собі & $34^{3}$ & $41^{1}$ & & $42^{1}$ & & & $40^{1}$ & & $50^{2}$ & $42^{1}$ \\
\hline Альтруїстична емпатія & & $44^{1}$ & & & & & & & & \\
\hline Емоційна експресивність & & & & & & & $40^{1}$ & & & \\
\hline Прийняття власних емоцій & & & & $-39^{1}$ & & & $-37^{1}$ & & $-34^{3}$ & $-34^{3}$ \\
\hline
\end{tabular}

Примітки: ${ }^{1}-p \leq 0,05,{ }^{2}-p \leq 0,01,{ }^{3}-p \leq 0,1 ; E I-$ емоційний інтелект, MEI - міжособистісний емоційний інтелект, УЧЕ - управління чужими емочіями, РЧЕ - розуміння чужих емоцій, ВЕI-внутрімньоособистісний емоційний інтелект, УВЕ - управління власними емочіями, РВE - розуміння власних емочій, КЕ - контроль експресії, $P E$ - розуміння емоцій, УE-управління емоцій, Зр - загальний рівень емоційного інтелекту; нулі та коми опущено

ного інтелекту. Заважає прояву загального емоційного інтелекту прийняття власних емоцій такими, якими вони $€(\mathrm{p} \leq 0,1)$.

Індиферентність $(\mathrm{p} \leq 0,1)$ та пасивна емпатія $(\mathrm{p} \leq 0,05)$ не заважають їм розуміти, контролювати власні емоції та проявляти досить високий емоційний інтелект у міжособистісній взаємодії. Безумовно, реальне сприяння $(\mathrm{p} \leq 0,05)$ та альтруїстична поведінка $(\mathrm{p} \leq 0,05) \in$ позитивними чинниками емоційного інтелекту, адже вони не залишають байдужими людей, до яких були проявлені, та допомагають налагодженню міжособистісної взаємодії.

Вплив антиемпатії $(\mathrm{p} \leq 0,05)$ на прояв емоційного інтелекту у дівчат $€$ амбівалентним: вона заважає розуміти чужі емоції та управляти ними, проте допомагає застосовувати маніпулятивні техніки для високих проявів міжособистісного, внутрішньоособистісного та емоційного інтелекту загалом.

Висновки. Не існує статевих відмінностей у показниках загального емоційного інтелекту, проте знайдено достовірні відмінності між показниками внутрішньоособистісного та міжособистісного емоційного інтелекту. Встановлено, що у дівчат краще розвинутий міжособистісний емоційний інтелект $(\mathrm{p} \leq 0,2)$, а у хлопців - внутрішньоособистісний $(\mathrm{p} \leq 0,1)$.

Знайдено статеві статистично значущі відмінності між особливостями функціонування внутрішніх чинників (інтегральної емпатії та іiі форм прояву, емоційної саморегуляції, прийняття власних емоцій) розвитку емоційного інтелекту. Виявлено достовірні відмінності між дівчатами та хлопцями у проявах дуже високого, високого та низького рівнів емпатії, а також формах іiі прояву (співчуття, внутрішнє сприяння, реальне сприяння не на шкоду собі та альтруїстична емпатія). У юнацькому віці дівчата більш схильні до сприяння не на шкоду собі, а хлопці - до альтруїстичної поведінки. У більшості дівчат виражена емоційна експресивність, вони легко та вільно виражають свої емоції. Хлопці краще приймають власні емоції, завдяки чому легко справляються 3 емоційними переживаннями.

Система чинників у дівчат $\epsilon$ більш широкою та амбівалентною порівняно з хлопцями. Домінуючими внутрішніми чинниками емоційного інтелекту у дівчат є як нижчі форми емпатії (індиферентність), так і вищі (сприяння не на шкоду собі, альтруїстична емпатія). Антиемпатія є амбівалентним чинником емоційного інтелекту, який заважає розуміти чужі емоції та управляти ними, проте допомагає застосовувати маніпулятивні техніки. У юнаків домінуючим внутрішнім чинником емоційного інтелекту є прийняття власних емоцій.

Перспективами подальших досліджень $є$ емпіричне визначення типів та рівнів розвитку емоційного інтелекту в юнацькому віці, дослідження його вікових та індивідуально-типологічних особливостей, доповнення досліджень взаємовпливу чинників розвитку емоційного інтелекту та його компонентів. 


\section{ЛІТЕРАТУРА}

1. Андреева И.Н. Понятие и структура эмоционального интеллекта. Социально-психологические проблемы ментальности : материалы 6 международной научно-практической конференции. Смоленск : издательство СГПУ, 2004. С. 22-23.

2. Гарднер Г. Структура разума: теория множественного интеллекта / пер. с англ. Москва : И.Д. Вильямс, 2007. С. 23-24.

3. Гарскова Г.Г. Введение понятия «эмоциональный интеллект» в психологическую теорию. Ананьевские чтения - 99 : тезисы научно-практической конференции. Санкт-Петербург : изд-во СПб. ун-та, 1999. С. 25-26.

4. Гоулман Д. Эмоциональный интеллект / пер. с англ. А.П. Исаевой. Москва : АСТ Москва, 2009. 478 с.

5. Журавльова Л.П. Діагностика емпатії та її форм у підлітковому та юнацькому віці. Науковий часопис Національного педагогічного університету імені М.П. Драгоманова. 2010. Вип. 31 (55). С. 154-161.

6. Журавльова Л.П., Лучків В.З. Дослідження асертивних стратегій поведінки в умовах рекреації. Наука і освіта. 2016. № 9. С. 59-63.

7. Журавльова Л.П., Шпак М.М. Емпатія як психологічний механізм розвитку міжособистісного емоційного інтелекту. Science and Education a New Dimension. Pedagogy and Psychology. 2015. № 3 (25). С. $85-88$.

8. Люсин Д.В. Новая методика для измерения эмоционального интеллекта: опросник ЭмИн. Психологическая диагностика. 2006. № 4. С. 3-22.

9. Люсин Д.В. Структура эмоционального интеллекта и связь его компонентов с индивидуальными особенностями: эмпирический анализ. Социальный интеллект: теория, измерение, исследования : сборник научных трудов. № 4. Москва : ИП РАН, 2004. С. 129-140.

10. Носенко Е.Л. Емоційний інтелект: концептуалізація феномена, основні функції : монографія. Київ : Вища школа, 2003. 126 с.

11. Півень М.А. Розробка методики діагностики емоційної зрілості особистості. Актуальні проблеми nсихології : збірник наукових праць Інституту психології імені Г.С. Костюка. Т. 11. Ч. 2. Київ, 2013. C. $224-232$.

12. Guastello D.D., Guastello S.J. Androgyny, gender role behavior, and emotional intelligence among college students and their parents. Sex Roles: A J. of Research. 2003. Dec. URL: http:// www.findarticles.com/p/articles.

13. Mayer J.D., Salovey P. What is emotional intelligence? Emotional development and emotional intelligence: educational implications. N.Y. : Perseus Books Group, 1997. P. 3-31.

14. Pietrulewicz B., Zhuravlova L. Significance of relationships and psychosocial adaptation during adolescence. Наука і освіта. 2016. № 5. С. 7-29.

\section{REFERENCES}

1. Andreeva I.N. (2004) Ponyatie i struktura emotsional'nogo intellekta [The concept and structure of emotional intelligence]. Sotsial'no-psikhologicheskie problemy mental'nosti: 6-ya mezhdunar. nauch.-prakt. konf. (Smolensk, 2004). Smolensk: SGPU, pp. 22-23.

2. Gardner Govard. (2007) Struktura razuma: teoriya mnozhestvennogo intellekta [The structure of mind: theory of multiple intelligences]. "I.D. Vil'yams", pp. 23-24.

3. Garskova G.G. (1999) Vvedenie ponyatiya "emotsional'nyy intellect" v psikhologicheskuyu teoriyu [Introduction of the concept of "emotional intelligence" into psychological theory]: Anan'evskie chteniya -99 , pp. 25-26.

4. Goulman D. (2009) Emotsional'nyy intellect [Emotional intelligence]. M.: ACT M., pp. 478.

5. Zhuravljova L.P. (2010) Diaghnostyka empatiji ta jiji form u pidlitkovomu ta junacjkomu vici [Diagnosis of empathy and its forms in adolescence and yang age]. Naukovyj chasopys Nacionaljnogho pedaghoghichnogho universytetu imeni M.P. Draghomanova, vol. 3, no. 55, pp. 154-161.

6. Zhuravljova L.P., Luchkiv V.Z. (2016) Doslidzhennja asertyvnykh strateghij povedinky v umovakh rekreaciji [Research of assertive strategies of behavior in the conditions of recreation]. Nauka $i$ osvita, no. 9, pp. 59-63.

7. Zhuravljova L.P., Shpak M.M., (2015) Empatija jak psykhologhichnyj mekhanizm rozvytku mizhosobystisnogho emocijnogho intelektu [Empathy as a psychological mechanism for the development of interpersonal emotional intelligence]. Science and Education a New Dimension. Pedagogy and Psychology, vol. III, no. 25, Budapest, pp. 85-88.

8. Lyusin D. V. (2006) Novaya metodika dlya izmereniya emotsional'nogo intellekta: oprosnik EmIn [A new technique for measuring emotional intelligence: the Emin questionnaire]. Psikhologicheskaya diagnostika, no. 4, pp. 3-22. 
9. Lyusin D.V. (2004) Struktura emotsional'nogo intellekta i svyaz' ego komponentov s individual'nymi osobennostyami: empiricheskiy analiz [The structure of emotional intelligence and the relationship of its components with individual characteristics: an empirical analysis]. Sotsial'nyy intellekt: teoriya, izmerenie, issledovaniya: sb. nauch. tr., Moskva: IP RAN, no. 4, pp. 129-140.

10. Nosenko E.L. (2003) Emocijnyj intelekt: konceptualyizacija fenomenu, osnovni funkcii [Emotional intelligence: conceptualization of the phenomenon, basic functions]: monoghrafija. K.: Vyshha shkola, pp. 126.

11. Pivenj M.A. (2013) Rozrobka metodyky diaghnostyky emocijnoji zrilosti osobystosti [Development of methods for diagnosing the emotional maturity of the individual]. Aktualjni problemy psykhologhiji: zbirnyk naukovykh pracj Instytutu psykhologhiji imeni Gh.S. Kostjuka. K. (T. 11), (Chastj 2), pp. 224-232.

12. Guastello D.D., Guastello S.J. (2003) Androgyny, gender role behavior, and emotional intelligence among college students and their parents. Sex Roles: A J. of Research. Dec. Retrieved from: $\mathrm{http}: / / \mathrm{www}$. findarticles.com/p/articles.

13. Mayer J.D., Salovey P. (1997). What is emotional intelligence? Emotional development and emotional intelligence: educational implications. N.Y.: Perseus Books Group, pp. 3-31.

14. Pietrulewicz B., Zhuravlova L. (2016). Significance of relationships and psychosocial adaptation during adolescence. Science and education, no. 5, pp. 7-29. 